Breaking the Logjam 
This page intentionally left blank 


\section{Breaking the Logjam}

Environmental Protection That Will Work

David Schoenbrod, Richard B. Stewart, Katrina M. Wyman

Illustrations by Deborah Paulus-Jagrič 
Published with assistance from the foundation established in memory of Calvin Chapin of the Class of 1788 , Yale College.

Copyright (c) 2010 by David Schoenbrod.

All rights reserved.

This book may not be reproduced, in whole or in part, including illustrations, in any form (beyond that copying permitted by Sections 107 and 108 of the U.S. Copyright Law and except by reviewers for the public press), without written permission from the publishers.

Designed by James J. Johnson and set in Photina Roman type by Keystone Typesetting, Inc., Orwigsburg, Pennsylvania.

Printed in the United States of America by Sheridan Books.

\section{Library of Congress Cataloging-in-Publication Data}

Schoenbrod, David.

Breaking the logjam : environmental protection that will work / David Schoenbrod, Richard B. Stewart, Katrina M. Wyman; illustrations by Deborah Paulus-Jagrič.

p. cm.

Includes bibliographical references and index. ISBN 978-0-300-14960-9 (hardcover : alk. paper)

1. Environmental law-United States. 2. Law reform-United States. I. Stewart, Richard B. II. Wyman, Katrina M., 1970- III. Title. KF3775.S365 2010

$344.7304^{\prime} 6-\mathrm{dc} 22$ 2009034627

A catalogue record for this book is available from the British Library. This paper meets the requirements of ANSI/NISO Z39.48-1992 (Permanence of Paper). 
To the pioneers of modern environmental protection 
At some time in the future-probably when this current version of gridlock is more apparent-we will be able to deal seriously with the reform we all recognize is needed. What would that reform look like?

—William D. Ruckelshaus, 1995 